\title{
Morphological characterization of vaginal epithelial cells of santa inês ewes subjected to estrus synchronization
}

\author{
Camila Vasconcelos Ribeiro', Tábatta Arrivabene Neves', Glaucia Brandão Fagundes, \\ Dayana Maria do Nascimento', Cleidson Manoel Gomes da Silva', Mônica Arrivabene', \\ Francisca Elda Ferreira Dias², Tânia Vasconcelos Cavalcante ${ }^{*}$
}

\author{
Federal University of Piaui, Bom Jesus, Brazil \\ ${ }^{2}$ Federal University of Tocantins, Araguaina, Brazil \\ *Corresponding author, e-mail: cavalcante.tv@gmail.com
}

\begin{abstract}
Vaginal cytology analysis has been used to evaluate the different stages of estrous cycle of several species; it presents a direct correlation with the animal's hormonal state and provides essential information about the female reproductive tract conditions. Two staining methods were tested to evaluate the vaginal epithelial cell morphology of nulliparous and multiparous ewes during the estrus period. An intravaginal device impregnated with medroxyprogesterone acetate was kept into 10 nulliparous and 10 multiparous ewes for 14 days for estrus synchronization. Then, the progesterone device was withdrawn, and $300 \mathrm{IU}$ of eCG was administered intramuscularly. Vaginal smears were prepared for posterior staining with Panotico or Giemsa stains when estrus was detected. The cells were classified into nucleated superficial, anucleate superficial, intermediate, parabasal, and basal. The Panotico and Giemsa staining of the different cell types studied were satisfactory. A predominance of intermediate epithelial cells $(p<0.05)$ was found after staining. No difference in percentages of the different types of vaginal epithelial cells between nulliparous and multiparous ewes were found. Therefore, both staining methods were efficient, and a predominance of intermediate cells is found in nulliparous and multiparous ewes during the estrus period.
\end{abstract}

Keywords: : sheep, cytology, ovine, reproduction

Introduction

Vaginal cytology analysis is a simple, noninvasive technique that has been successfully used to predict the different phases of the estrous cycle in different species (Sharma \& Sharma, 2016). Several studies have sought to improve this technique and incorporate it as an essential part of the gynecological examination in goats (Leigh et al., 2010), bitches (Leigh et al., 2013), sows (Vidal et al., 2013), ewes (Zohara et al., 2014), and cows (Siregar et al., 2016).

Vaginal cytology analysis can be performed immediately after collection, in wet, or non-stained (direct cytology) mounts, or after smear preparation that should be fixed and

stained (Cora et al., 2015). It is a standardized technique; however, its preparation step is still under discussions, mainly regarding the type of stain to be used. The main methods that result in good staining include Giemsa, Leishman, Shorr's, or other Romanowsky type stains (Cora et al., 2015).

The cytological profile of vaginal epithelium cells can facilitate reproductive and productive managements of sheep (Porto et al., 2007). According to Zohara et al. (2014), the vaginal epithelium of ewes undergoes marked cytological changes during the estrous cycle, causing the appearance of different types of epithelial cells. However, no study 
evaluating the difference of cytological profiles of vaginal epithelial cells between nulliparous and multiparous ewes has been developed. Therefore, the objective of the present work was to compare different staining methods to evaluate the morphology of vaginal epithelial cells of nulliparous and multiparous ewes during the estrus period.

\section{Material and Methods}

The present work was reviewed and approved by the Animal Experimentation Ethics Committee of the Federal University of Piaui (protocol number: 034/15). The study was carried out at the Santa Teresa farm, in Matões, state of Maranhão, Brazil $\left(5^{\circ} 05^{\prime} 21^{\prime \prime} \mathrm{S}, 42^{\circ} 48^{\prime} 07^{\prime \prime} \mathrm{W}\right.$, and 74.4 meters of altitude). The region has an average annual rainfall of 1000 to $1800 \mathrm{~mm}$, and average annual temperature of $36.7^{\circ} \mathrm{C}$.

The experiment was carried out in December 2016, using 20 clinically healthy Santa Ines ewes-10 nulliparous and 10 multiparous. These animals were maintained in a semiintensive system, with access to water.

An intravaginal device impregnated with medroxyprogesterone acetate (Progespon ${ }^{\circledast}$, Syntex, Argentina) was kept in each ewe for 14 days. Then, the progesterone device was withdrawn, and $300 \mathrm{IU}$ of equine chorionic gonadotrophic was administered intramuscularly to each ewe (eCG, Novormon ${ }^{\circledast}$, Syntex, Argentina) (Abecia et al., 2011).

The estrus was detected by analyzing the animal's behavior, with the aid of rams, for a period of $72 \mathrm{~h}$ after removal of the intravaginal device. When estrus was detected, the ewe was contained, and wet antisepsis of the external genitalia was performed with water and neutral soap.

The vulvar lips of the ewe were spread, and a disposable, sterile cotton swab was introduced at the dorsal commissure of the vulva in a dorsal-cranial direction, until it passed through the sciatic arch, to collect cells from the vaginal epithelium. The swab was then rotated on the vaginal vestibule and removed to transfer the collected material to identified glass slides.

The smearing was done by rotating the swab on the slide. Two vaginal smears per ewe were made. The slides were sent to the Laboratory of Animal Reproduction Biotechnology of the Federal University of Piauí (UFPI), Brazil, and fixed in methanol. Two staining methods were used: Panotico Rapido, and Giemsa.

Panotico staining was performed according to the following procedures: slides were immersed in (1) $0.1 \%$ triarylmethane solution, (2) $0.1 \%$ xanthene solution, and (3) $0.1 \%$ thiazine solution; the slides were kept in each solution for 5 seconds. Then, they were washed with running water and left to dry for further microscopic evaluation.

Giemsa staining was performed by diluting the stain in distilled water at 1:2 ratio (1 $\mathrm{ml}$ of Giemsa and $2 \mathrm{ml}$ of distilled water) using a Pasteur pipette. Then, the solution was placed onto the smears and left for about two hours. The slides were then washed with tap water and left to dry for further microscopic evaluation.

After the staining with Panotico or Giemsa, the cells found in the vaginal smears were classified based on their morphological characteristics as: nucleated superficial, anucleate superficial, intermediate, parabasal, and basal cells (Guimarães et al., 2011). The percentage of each cell type was calculated by the formula: [(number of cells identified / total number of cells) $\times 100]$.

The results were analyzed using the BioEstat 5.0 statistical program. The percentages of vaginal epithelial cells after staining with each stain (Panotico and Giemsa stains) were compared in each animal category (nulliparas and multiparas) using the chi-square test, considering a $5 \%$ significance level $(p<0.05)$.

\section{Results and Discussion}

The different types of cells found after the Panotico or Giemsa staining are shown in Figure 1. Nucleated superficial cells and anucleate superficial cells presented a polygonal shape, with presence of an intact or pyknotic nucleus in the latter. Intermediate cells presented a rounded shape with a centralized nucleus and an abundant cytoplasm. Parabasal cells presented an oval or spherical shape, little cytoplasm, and a central or peripherally nucleus. Basal cells presented a spherical shape, with a nucleus 
occupying almost all cellular cytoplasm.

The Panotico and Giemsa staining methods were efficient for the analysis of vaginal epithelial cells of ewes, and allowed an adequate observation of the cell population in the vaginal epithelium of ewes and an accurate cell morphological characterization.

The proportion of each type of vaginal epithelial cell of ewes, during the estrus manifestation, is shown in Table 1.
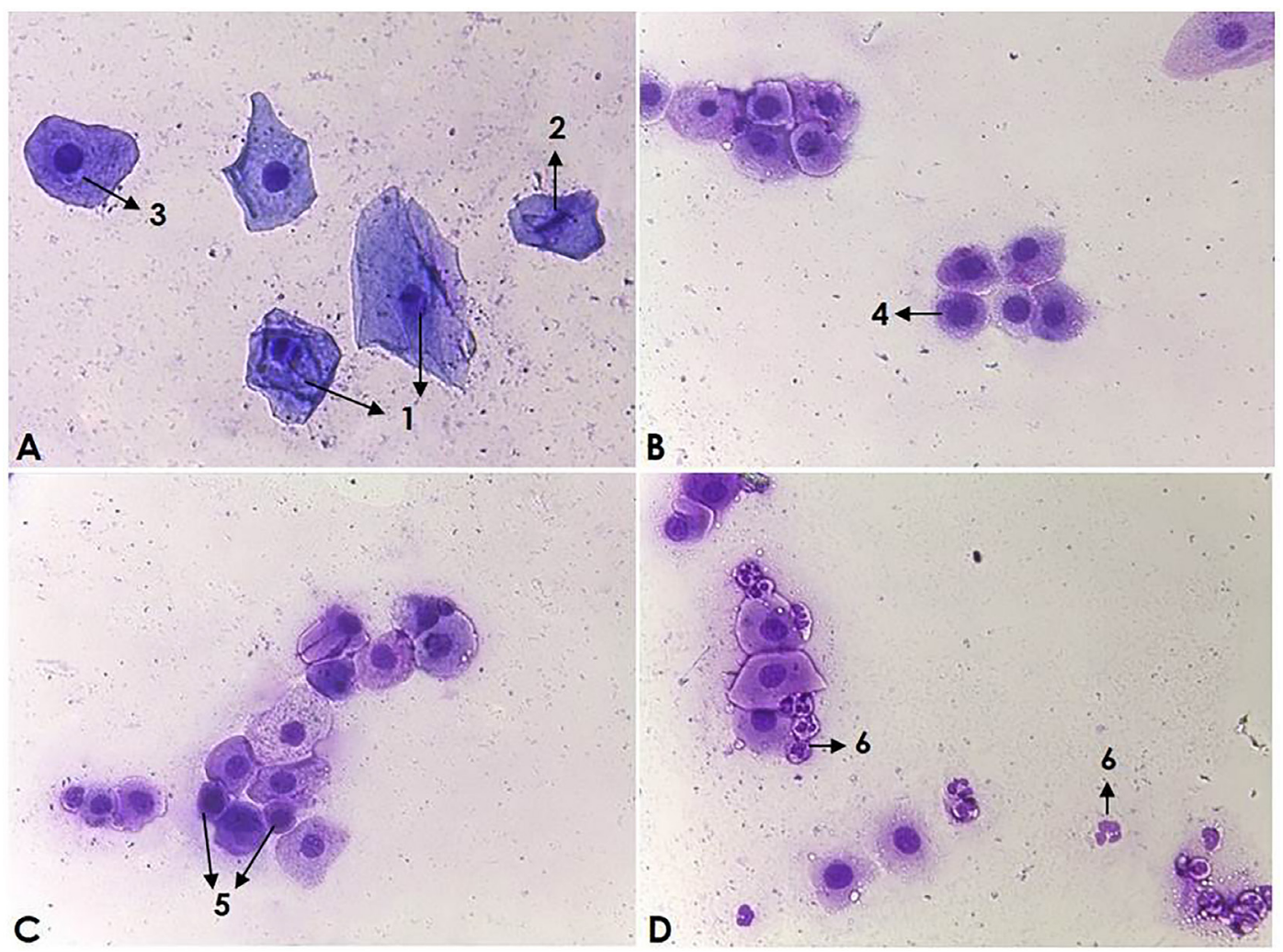

Figure 1. Photomicrographs of vaginal epithelial cells of ewes, during induced estrus, stained with Panotico (1A and 1B) or Giemsa (1C and ID) stains, and observed under a 40x objective. Nucleated superficial cells (1), anucleate superficial cells (2), intermediate cells (3), parabasal cells (4), basal cells (5), and neutrophils (6).

Table 1. Percentage (\%) of different types of vaginal epithelial cells of Santa Inês ewes after staining with Panotico or Giemsa stains.

\begin{tabular}{lcc}
\hline \multirow{2}{*}{ Cell type } & \multicolumn{2}{c}{ Staining method } \\
\cline { 2 - 3 } & Panotico & Giemsa \\
\hline Nucleated superficial & $32(4.00)^{\mathrm{bc}}$ & $26(3.25)^{\mathrm{bc}}$ \\
Anucleate superficial & $28(3.50)^{\mathrm{bc}}$ & $19(2.37)^{\mathrm{bc}}$ \\
Intermediate & $663(82.80)^{\mathrm{a}}$ & $680(85.00)^{\mathrm{a}}$ \\
Parabasal & $65(8.12)^{\mathrm{b}}$ & $60(7.50)^{\mathrm{b}}$ \\
Basal & $12(1.50)^{\mathrm{c}}$ & $11(1.37)^{\mathrm{c}}$ \\
Total & $800(100.00)$ & $800(100.00)$ \\
\hline Means followed by different letters in the same column are significantly different by the chisquare test $(p<0.05)$. &
\end{tabular}

In all smears evaluated, a predominance $(p<0.05)$ of intermediate epithelial cells was found after Panotico (82.8\%) and Giemsa (85.0\%) staining. However, no significant difference was found between the staining methods for the proportion of the different cell types.

The percentage of different epithelial cell types found in the vaginal smears was similar ( $p>0.05$ ) between nulliparous and multiparous ewes (Table 2).
The staining of vaginal smears with Panotico or Giemsa has been reported as a way to identify the different phases of the estrous cycle in ewes (Porto et al., 2007; Zohara et al., 2014). However, no studies have compared these two staining methods.

The Panotico and Giemsa staining methods were efficient, allowing the identification of different types of vaginal epithelial cells of Santa Inês ewes during the estrus period. However, 
Panotico staining presented some advantages, because Panotico is a readily available, easy to use, low cost product, and has a faster staining when compared to Giemsa stain.

Table 2. Percentage (\%) of different types of vaginal epithelial cells in nulliparous and multiparous Santa Inês ewes during induced estrus.

\begin{tabular}{lcc}
\hline Cell type & Nulliparous $(\mathrm{n}=10)$ & Multiparous $(\mathrm{n}=10)$ \\
\hline Nucleated superficial & $16(2.00)$ & $32(4.00)$ \\
Anucleate superficial & $35(4.37)$ & $28(3.50)$ \\
Intermediate & $600(75.00)$ & $663(82.87)$ \\
Parabasal & $127(15.87)$ & $65(8.12)$ \\
Basal & $22(2.75)$ & $12(1.50)$ \\
Total & $800(100.00)$ & $800(100.00)$ \\
\hline No significant difference was found by the chisquare test (p<0.05). & &
\end{tabular}

Regarding the proportion of the different types of vaginal epithelial cells of ewes, a predominance of intermediate cells was found after Panotico (82.80\%) and Giemsa (85.00\%) staining. Porto et al. (2007) found different results when evaluating the vaginal cytological profile of Santa Inês ewes, with a greater number of anucleate superficial cells $(29.56 \%)$ in smears after Panotico staining. Moreover, Zohara et al. (2014) found predominance of superficial cells $(61.70 \%)$ in smears from native ewes after Giemsa staining. These differences may be due to different methodologies of evaluation, since the collection of the vaginal swabs in the studies of Porto et al. (2007) and Zohara et al. (2014) were obtained from ewes that presented natural estrus. According to Pérez-Martínez et al. (1999), the exogenous administration of steroid hormones directly influences the vaginal cytological profile in goats.

The reproductive performance of nulliparous ewes is unsatisfactory compared to multiparous ewes, mainly due to their reduced ovulation rate, failures in mating, failures in fertilization, and loss of embryos (Edwards et al., 2016). However, no differences between nulliparous and multiparous ewes were found for the percentages of vaginal epithelial cells under the experimental conditions of the present study. This is probably related to the use of the same hormonal protocol for estrus synchronization and ovulation induction for all experimental animals.

In addition to the different types of cells of the vaginal epithelium found, neutrophils were found in some vaginal smears from nulliparous and multiparous ewes. According to Groppetti et al. (2012), the presence of neutrophils during the proestrus and estrus phases is due to physiological factors in bitches, and these neutrophils extravasate from blood vessels to the vaginal lumen by diapedesis, attracted by the presence of bacteria. However, the presence of neutrophils in vaginal smears has received little attention in cyclic animals (Mattos et al., 2003), except in cases of intense infiltration, which is a characteristic during the period of uterine involution in the postpartum period and in cases of metritis (Groppetti et al., 2012; Sharma \& Sharma, 2016).

\section{Conclusion}

The Panotico stain and Giemsa stain were efficient for the staining of vaginal epithelial cells of Santa Inês ewes. However, the Panotico stain is recommended due to its easier use and faster staining.

A predominance of intermediate cells in the vaginal smears was found during the induced estrus of Santa Inês ewes in both animal categories (nulliparous and multiparous ewes). However, further studies are required to evaluate alterations in the cytological profile of vaginal epithelial cells of ewes due to the commonly used protocols for estrus synchronization and ovulation induction.

\section{References}

Abecia, J.A., Forcada, F., González-Bulnes, A. 2011. Pharmaceutical control of reproduction in sheep and goats. Veterinary Clinics of North America: Food Animal Practice, 27: 67-79.

Cora, M.C., Kooistra, L., Travlos, G. 2015. Vaginal cytology of the laboratory rat and mouse: review and criteria for the staging of the estrous cycle using stained vaginal smears. Toxicologic Pathology, 43: 776-793.

Edwards, S.J., Smaill, B., O'Connell, A.R., 
Johnstone, P.D., Stevens, D.R., Quirke, L.D., Farquhar, P.A., Juengel, J.L. 2016. Reduced ovulation rate, failure to be mated and fertilization failure/embryo loss are the underlying causes of poor reproductive performance in juvenile ewes. Animal Reproduction Science, 167: 125-132.

Groppetti, D., Pecilea, A., Barberoa, C., Martino, P.A. 2012. Vaginal bacterial flora and cytology in proestrous bitches: Role on fertility. Theriogenology, 77: 1549-1556.

Guimarães, D.A.A., Garcia, S.C.G., Le Pendu, Y., Albuquerque, N.I. 2011. Determinação do ciclo estral em catetos Pecari tajacu: aspectos colpocitológicos e clínicos. Acta Amazonica, 41: 583-588.

Leigh, O., Raji, L., Diakodue, E. 2013. Detection of standing heat in bitches: application of vaginal cytology. World Journal Life Science and Medical Research, 3: 21-25.

Leigh, O.O., Raheem, A.K., Oluwadamilare, O.J.A. 2010. Improving the reproductive efficiency of the goat: vaginal cytology and vulvar biometry as predictors of synchronized estrus/breeding time in West African dwarf goat. International Journal Morphology, 28: 923-928.

Pérez-Martínez, M., Mendoza, M.E., Romano, M.C. 1999. Exfoliative vaginal cytology and plasma levels of estrone and estradiol-17 $\beta$ in young and adult goats. Small Ruminant Research, 33: 153158.

Porto, R.R.M., Cavalcante, T.V., Dias, F.E.F. Rocha, J.M.N. Souza, J.A.T. 2007. Perfil citológico vaginal de ovelhas da raça Santa Inês no acompanhamento do ciclo estral. Ciência Animal Brasileira, 8: 521-527.

Sharma, M., Sharma, N. 2016. Vaginal cytology: An historical perspective on its diagnostic use. Advances Animal in Veterinary Science, 4: 283288.

Siregar, T.N., Melia, J., Rohaya, Thasmi C.N., Masyitha, D., Wahyuni, S., Rosa, J., Nurhafni, Panjaitan, B., Herrialfian. 2016. Determining proportion of exfoliative vaginal cell during various stages of estrus cycle using vaginal cytology techniques in aceh cattle. Veterinary Medicine International, http://dx.doi. org/10.1155/2016/3976125.

Vidal, B.R., Silva, G.F.D., Santos, J.S., Dias, F.E.F., Lima, A.K.F., Viana, E.B., Neves, W.C., Viana, G.E.N., Gomes, M.G.T., Cavalcante, T.V. 2013. Estrus identification through colpocytology in sows in intensive free-range breeding. Journal of Veterinary Advances, 3: 281-284.

Zohara, B.F., Azizunnesa, Islam, M.F., Alam, G.S., Bari, F.Y. 2014. Exfoliative vaginal cytology and serum progesterone during the estrous cycle of indigenous ewes in Bangladesh. Journal of Embryo Transfer, 29: 183-188. 